\title{
The Analysis of Creative Thingking Ability in Science Subject Matter of the Fourth Grade Students in SD N. 2 Pemaron Buleleng Sub-Distric
}

\author{
Sekar, Desak Ketut Sarining \\ Ganesha University of Education \\ dessakketutsariningsekar@yahoo.co.id
}

\begin{abstract}
This study aimed to describe the creative thinking abilities of students in science lessons, describe the obstacles faced by teachers in improving the thinking skills of fourth grade in elementary school No. 2 Pemaron Buleleng and describe the efforts of teachers in improving the thinking skills of fourth grade in elementary school No. 2 Pemaron Buleleng. This type of research is qualitative descriptive. The subjects were students of class IV and science teachers, while the object of this study is the ability to think creatively IPA on students. Results of this study are as much as $46.45 \%$ of students scored below average including medium category. Results of the indicator analysis shows that original thinking is an indicator with the highest percentage of the total percentage of $84.17 \%$ of the indicators of current thinking, thinking elaborative and indicators to think flexibly. Constraints faced in the ability to think creatively is the interest of students is still low, inadequate facilities, lack of utilization of the environment as a source of learning, learning methods that are less attractive and less parental supervision of their children's learning activities. Efforts are being made to improve the ability to think creatively IPA, among others, teachers use a more varied learning methods and implement learning activities more interesting and fun as more invites students to conduct experiments in the classroom or outside the classroom.
\end{abstract}

Keywords: qualitative descriptive science lesson, the ability to think creatively.

\section{Introduction}

Education plays an important role in preparing qualified human resources to be able to compete in the face of the development of science and technology. In PP no.19 of 2005 regarding National Standards, it elaborated that "one of the missions of competitiveness at the national level is to improve the quality of education that has relevance of education to the needs of the community in efforts to meet global challenges". Therefore education should be implemented as well as possible in order to obtain maximum results. Education should be managed as much as possible, both in quality and quantity. In this regard, the Indonesian government had taken great efforts to improve national education system, which was done by curriculum improvement, undertaking training on the quality of teachers, provision of educational facilities and infrastructure improvements as well as improving the quality of management education.

As explained in the Kurikulum Tingkat Satuan Pendidikan (School Based Curriculum), 2006 which suggests that the learning process should be able to develop all the potential of the student. It has the purpose to develop all the potential of the learners. The purpose of all education is to provide students enviroment that allow participants to be able to develop the ability (potential), particularly in terms of enhancing creative thinking optimally. School Based Curriculum is very likely for every school to emphasize and develop subjects which is considered the most needed for students. School Based Curriculum also requires students to be active and creative in learning. The role of creativity stressed that the curriculum should be able to develop something new in accordance with developments and the needs of society in the present and the future. The curriculum should be able to contain things that 
can help students develop all the potential in him to acquire new knowledge, new skills and new ways of thinking needed in life.

Thus, an education could improve creative thinking ability of students when studying in elementary school. The teacher as a facilitator in the learning process should be able to understand it. Creative thinking is a thought process that produces an assortment of answers. Creative thinking is also seen as process that is used when an individual brings or bring up a new idea. Creative thinking is characterized by the new idea that emerged as a result of the thinking process.

A good creative thinking skill in students could determine the success in learning. Moch Sholeh (1988: 197), "in understanding the conditions necessary for creative thinking, teachers can encourage and nurture creative talent development and realizing students talents which are still buried.".

Creativity could be viewed as the product of creative thinking, while the creative activity is an activity that directed to encourage or bring creativity to make students to think creatively. Future challenges are always changing and at the same time competition require more stringent educational graduate that are not only skilled in a field, but also creative in developing their field. It needs to be manifested in every subject in school, it include (Science) which must be given to all learners from primary schools to prepare learners with the ability to think logically, analytically, systematically, critically, and creatively, as well as the ability to work together.

Science is defined as a body of knowledge that is arranged with guidance.This is in line with the way of finding out about nature systematicaly, so not only the mastery of knowledge in the form of a collection of facts, concepts or principles but also a process of discovery. As already mentioned, developing logical, analytical, systematic, critical, or cooperation thinking ability has long been a focus of attention of the audience and science educators (IPA) in the class, because it is related to the nature of science and scientific characteristics. However, focus and attention on improving the ability of creative thinking in science (IPA). Creative thinking in this case is thought processes which can make variety of idea which is not exist before.

Based on the above explanation, it became very interesting to study how creative thinking skills in learning science in SD Negeri 2 Pemaron. For that research with the purpose of (1) To describe the profile of creative thinking in the fourth grade students in SD No. 2 Pemaron Buleleng, (2) To describe problems faced by teachers in improving the thinking skills of fourth grade in SD No. 2 Pemaron Buleleng regency, and (3) to describe the efforts of teachers in improving the ability to think for the fourth grade in SD No 2 Pemaron Buleleng.

\section{Research Methods}

This study used qualitative research methods which required in-depth data which mean meaningful data (Sugiyono, 2012). Descriptive research was defined as a study that tried to describe a phenomenon / events systematically in response to what it was. Descriptive study was conducted to obtain information about the current state. In such studies, the researchers tried to determine the nature of the situation as it was at the time of the study happened. In a descriptive study no control group exist like in experimental studies because its purpose was to describe "what it is" associated with variables or conditions in a given situation. Descriptive studies were generally not geared to test the hypothesis.

This research was carried out only in one place that was in SD No. 2 Pemaron Buleleng. Researchers chosed SD No. 2 Pemaron because this elementary school was quite normal based on the criteria. The research subject or source of data in this study was the fourth grade elementary school students and teachers of the fourth grade in SD No. 2 Pemaron. In this school only one class was taken as a data source. Determining the informants in this study was done using purposive procedure that was chosen by consideration and specific purposes 
(Sugiyono, 2009). The object of this research was the ability to think creatively in learning science in SD No. 2 Pemaron.

Data were collected by using observation, testing, and interviews. The test that was used to obtain the data on students' ability to think creatively in Science class was an essay test totaling 10 questions. The test was based on indicators of creative thinking abilities which included smoth thinking, flexible thinking, original thinking and elaborative thinking. While the type of interview which was used was semi- structured interviews with the matter amounted to 10 questions. Interview was given to the science teacher.

However, before being used in the study, the research instrument first needed to be tested. Trial or validity of the instrument was made to obtain a picture of the feasibility of the instruments used in the study. In this study, the test was given to fourth grade students at SDN 1 Pemaron with total students of 40 students. The try out results were then analyzed to determine the validity of the test, reliability test, test of different power, and the level of difficulty of the test. From 10 questions which were tested, all questions were said to be valid and could be used in the research.

Data that were collected during the study was analyzed using descriptive statistical analysis which included the mean, median, mode, maximum data, minimum data, variance, standard deviation, and range. And also analyzed using descriptive percentages to determine the percentage of each indicators mastery of creative thinking.

\section{Finding}

\section{Finding and Discussion}

Science creative thinking ability test was given to students in grade IV in SD Negeri 2 Pemaron. Of the 30 students in SD Negeri 2 Pemaron, the highest score obtained was 100 and the lowest score obtained was 60. If the test result of the ability to think creatively in Science was presented in a frequency distribution table, it would be as follows.

The results of the test of the capabilities in creativethinking in Science in SD Negeri 2 Pemaron could be seen in Table 1.

Table 1. Frequency distribution of creative thinking ability test results in science for students in fourth grade at SD Negeri 2 Pemaron

\begin{tabular}{ccccc}
\hline No & Score Interval & Median & Frequency & F relative $(\%)$ \\
\hline $\mathbf{1}$ & $60-65$ & 62.5 & 5 & 17.85 \\
$\mathbf{2}$ & $66-71$ & 68.5 & 3 & 3.6 \\
$\mathbf{3}$ & $72-77$ & 74.5 & 6 & 25.00 \\
$\mathbf{4}$ & $78-83$ & 80.5 & 3 & 10.71 \\
$\mathbf{5}$ & $84-90$ & 86.5 & 6 & 21.42 \\
$\mathbf{6}$ & $91-96$ & 95.5 & 3 & 7.14 \\
$\mathbf{7}$ & $97-102$ & 99.5 & 4 & 14.28 \\
\hline
\end{tabular}

Figure 1 showed that the score that learners obtained tend to vary. The highest score that ranges between 97-102 were obtained approximately by 4 learners, while the lowest score in the interval 60-65 was obtained about by 5 learners.

The ability to think creatively in this study was assessed using four indicators, namely 1) Smooth Thinking, 2) Flexible Thinking, 3) Original Thinking, and 4) elaborative thinking. Data about creative thinking was collected using essay test which used the indicator of the ability to think creatively as the base. Each indicator should be analyzed to determine the percentage of successful students in developing their creative thinking skills. Analyisis of indicator of the ability to think creatively in Science was calculated using the formula of descriptive percentage (DP). If the percentage of an indicator was high, it means the creative 
thinking skills of learners in science lessons was also high.

From the data gathered, it showed that the indicators of smooth thinking, flexible thinking, original thinking and elaborative thinking alike had categorized as high with the highest percentage amount on original thinking indicators which was $84.17 \%$, smooth thinking was $83.33 \%$ elaborative thinking was $79,17 \%$ and the flexible thinking was $77.08 \%$.

In general, problem in developing learners creative thinking to answer the question was due to the process of learning science still dominantly used the lecture method, and science learning condition was not centered on students, because all activities were dominated by teachers so that students became less active.

In general, the problems experienced by learners in learning, especially in science lessons were problems in developing their creative thinking skills. Problems in developing creative thinking skills included, problems in smooth thingking, flexible thinking, original thinking, and in elaborative thinking.

In this study, researchers did a discussion with the fourth grade teacher in the school of SD Negeri 2 Pemaron to find solution to the problems of developing creative thinking abilities in Science experienced by learners. After an agreement was reached it was decided that in order to overcome the problems experienced by learners, efforts that should be made was by using a more varied learning methods and also by carrying out the activities of learning interestingly and more fun, for example invited students to conduct experiments in class or outside the classroom. Learning method was one of the most influential things to be done in developing the creative thinking abilities of learners. Selecting an appropriate method capabled of making quick learners understand the concept of what being taught and developing their creative thinking skills, on the other hand using less precise method could make students slower in understanding the concepts even not able to understand the concepts of what being taught.

The method most often used by teachers in teaching the material was a lecture. This method was considered the most effective in explaining the materials about Science, because students could quickly understand the material being taught, but was unable to make students develop their creative thinking. But the problem was when you used the lecture method, only a small fraction of students were really able to understand the material, while the other did not understand the material but only memorize some of the material. Besides the lecture method another method often used was the question and answer method, this method was used because the teacher thought it could assess the ability of learners in creative thinking. Teachers could see students creative thinking through the answers given when answering questions from the teacher. Both methods which were often used by teachers could be combined with the use of other learning methods that were able to develop active learners, the method was a method of group discussions and project based methods. In the group discussion method, students were asked to discuss an issue together with the group. Here, students not only acquire knowledge, but also able to learn about how to work together, respect each other, and share knowledge. The project based method was used to promote creativity owned by learners. With this method, students were asked to produce a work that was associated with the content, such as a project to make a replica of forest affected by floods when the discussion was about the impact of forest resources that are not conserved. With the use of those various methods, such as lectures, discussion, group discussion, and the project based, it was expected that learners were able to understand the concepts of what being taught by teachers so that students could easily applied the ability to think creative, than when teachers teach using only the lecture method and question and answer.

In addition to the use of varied methods, other measures that had been agreed by researcher and teachers were to carry out interesting and fun activities. The meanings of the activities that are interesting and fun were activities which were performed outside the 
classroom in the form of observations and experiments. These activities took advantage of the natural surroundings as a place of learning and learning resources. This made the learners could find directly the concept that was being taught so that students were able to master the four indicators of the ability of creative thinking which were thinking fluently, flexible thinking, original thinking and elaborative thinking. Learners also not just memorizing the material, but really mastering the material that could last long. From the attempts that have been agreed, it was hoped that learners really able to develop and implement creative thinking abilities while answering questions in the learning process or test resulting in an interesting, varied and elaborate details of answers. Based on the tests that had been conducted in SD Negeri 2 Pemaron, it obtained varied test results which showed creative thinking skills. Each learner acquired different result that could indicate their level of creative thinking skills. The following explanation of the test results of creative thinking abilities in Science. Science creative thinking ability test in SD Negeri 2 Pemaron was conducted on Friday, April 10, 2015. This test was given to students in fourth grade totaling 30 students. Science creative thinking ability test consists of 10 essay questions which were made based on indicators of creative thinking abilities which are indicators of smooth thinking, flexible thinking, original thinking and elaborative thinking indicators. The test results obtained by the fourth grade students of SD Negeri 2 Pemaron was quite satisfactory, it could be seen from the result obtained by the learners. The highest score obtained was 100 and the lowest score obtained was 60. Based on these results, the average of the test was 79.78 which could be categorized as high. From the 30 students, 3 students or $10.71 \%$ gained score which wass equal to the average, 14 students or $46.45 \%$ scored below average, and 13 students or $42.84 \%$ gained score above average.

To further determine the ability to think creatively in Science, analysis was done on the indicators which were tested. These indicators included indicators of smooth thinking, flexible thinking, original thinking and elaborative thinking indicators. For the indicator of smooth thinking indicator the percentage of learners who could answer the questions correctly was $83.33 \%$ or equal to 25 students, while the remaining $16.67 \%$ or equal to 5 learners were not able to answer the questions correctly.

The second indicator was an indicator of flexible thinking which was an indicator with the lowest percentages at the percentage rate of $77.08 \%$ or equal to 23 learners were able to answer correctly. While the remaining $22.92 \%$ or equal to 7 learners were still not able to answer questions relating to giving an example and an explaining.

The third indicator is the indicator of original thinking. The results obtained of original thinking indicator was $85.17 \%$, equivalent to 25 learners who were able to answer questions correctly, whereas $15.83 \%$ or 5 learners were still not able to answer correctly. The fourth indicator was the indicator of elaborative thinking with percentage equal to $79.17 \%$ or 24 learners who could answer the questions correctly, whereas $20.83 \%$ or 6 learners still got wrong answer about the elaborative thinking.

Based on the above presentation, it could be concluded that indicators of flexible thinking was an indicator with the lowest percentage which was at $77.08 \%$, while the indicator of original thinking was an indicator of the ability to think creatively with the highest percentage which was at $84.17 \%$.

\section{Discussion}

Implementation of learning process did not always run smoothly, it would have encountered many problems such as the interest of learners which was low, learning facilities which were inadequate, the lack of utilization of the environment as a learning resource, learning time was quite short at school, did not get close attention of the learners, learning method was monotonous like a lecture and often students only memorize material. As it was 
known that the interests of students affect the ability to think creatively in Science which was taught by the teacher. If the interest of students towards science subjects was low, then the ability to think creatively that would be earned would be less as well, however, if students had a strong interest in science lessons, the ability to think creatively owned by learners would be high too. Things that could affect the interest of learners were the way teachers teach.

The next problem was learning facilities which were inadequate and still need to be renovated. As previously described facilities played an important role in enhancing the creative thinking skills of learners. Supporting facilities needed in primary schools included textbooks, teaching aids, and other amenities. If facilities were available in school were adequate and could support the learning process, it was more likely for learners to develop and implement creative thinking abilities, but on the contrary if the school did not have the supporting facilities, the learners would had difficulties to develop and applying creative thinking abilities in Science. In addition to the lack of supporting facilities, the problem often faced was the lack of utilization of the natural environment as a learning resource. Learning science conducted in SD largely confined in the classroom which was to listen to the lectures of teachers it was because the time to learn science at school was quite short. Information which was obtained by learners was only obtained from teachers and books. Even though resources that will never run out was around us which was environment.

The next problem was the lack of attention from parents when students learn at home. This made learners lazy to learn and ask when they learn at home, because learners were not accompanied by their parents. If learners were lazy to learn and ask then when at school students would just sat and listened but did not understand the material taught by teachers. This made it difficult for teacher to teach creativity for the learners.

From these questions, teachers could draw conclusion that the learners in the learning process in Science subject need to have a sense of excitement and enthusiasm so that teachers could measure the ability of creative thinking. For learners who were able to apply their creative thinking skills, teachers only need to sharpen it so that learners were able to apply it in all circumstances and conditions. As for students who had not been able to apply creative thinking skills, the teacher must use new methods and made approaches to the learners in the process of science learning and sharing ideas with the parents of students in order to provide the same guidance. So at home and at school, students got the same guidance.

The way to overcome or avoid the problems were of course depend on the types of problems that, whether external or internal, whether it was an intellectual, emotional, or a perceptual problem. To develop creative thinking abilities of learners, teachers should cultivate an attitude of curiosity in students, giving challenge to learner, foster a sense of dissatisfaction with what was there, to gain confidence that the problem could certainly be solved, and teaching mindset that the problem could certainly be solved.

Judging from the problems of teachers, teachers' efforts in SD Negeri 2 Pemaron for overcoming the problems was to develop learners' creative thinking abilities among other teachers by using varied learning methods and also carrying out activities which were intresting and fun. For example, giving more chance for students to conduct experiments in the classroom or outside the classroom. Selection of appropriate methods which was capable of making learners understand quickly the concept that was being taught and developed their creative thinking skills, on the other hand using less precise method would made students slower in understanding the concepts even wasn't able to understand the concepts that was being taught.

Besides lecture method, another method often used was the question and answer method, this method was used because the teacher thought, it could assess the ability of learners in creative thinking in Science. Teachers could see students creative thinking through the answers given when answering questions from the teacher. 
Both methods which were often used by teachers could be combined with the use of other learning methods that were able to develop active learners, the method was a method of group discussions and project based methods. In the method of group discussion, students were asked to discuss an issue together with the group. Here, students not only acquire knowledge, but also be able to learn about how to work together, respect each other, and share knowledge. While the Project Based method was used to promote creativity the learners had. With this method, students were asked to produce a work that is associated with the material, such as a project to make a replica of forest affected by floods when the discussion about the impact of forest resources that are not conserved was done. With the use of various methods, such as lectures, discussion, group discussions and projects based, learners were expected to be able to understand the concepts being taught by the teacher so that students could easily afford to apply their ability to do creative more thinking, than when teachers taught only by using the method of lecture and question and answer.

In addition to the use of varied methods, other measures that had been agreed between researchers and classroom teachers were to carry out interesting and fun activities. The meaning of interesting and fun activities was to do activities outside the classroom in the form of observations and experiments. These activities took advantage of the natural environment as a place of learning and learning resources. This made the learners could find the knowledge being taught directly which made students were able to master the four indicators of the ability of creative thinking which were Smooth thinking, flexible thinking, original thinking and elaborative thinking. Learners also not only just memorizing, but really mastering the material that could last long.

From all the means that had been agreed, it was hoped that learners would really able to develop and implement creative thinking abilities while answering questions in the learning process or test resulting in interesting, varied and elaborate answers. The above explanation also deals with the power of score prediction of the creativity tests which explained that someone could not braged about themselves for their score in creativity when at school, without showing any effort to make it happen for real, because what was measured was the potential to be creative, (Supriyadi, 1994: 34 ).

In manual TTCT, Torrance (1974: 6) stated that "even though we found that children who score high but not become a creative person as an adult, it doesn't means the test is invalid or not useful for educators to know the potential of intellect or the learners". Second argument, was that what was detected by the test of creativity was a person's capacity to grow or creative potential. As the same in any field, the actualization of the potential depended on environmental conditions, motivation, and commitment of a person to develop themselves. High level of creativity did not determine someone will be among the high creative achievements in adult life later on without the help of effort and hard work. Therefore, there could be people who had low score in creativity and demonstrated high achievement in life. Instead the one with high scores had a poor performance, although the ideal, there was a high correlation between the two. Symptoms when score someone had was high but they had lower achievement was typically called "low achievement" (under-achievement). On the other hand, a low score but with high achievement was called the "over achievement" (over-achievement). Some studies found that the symptoms that made under-achievements were because of environment which was not supportive, unstable emotion and weak motivation (Supriya, 1994: $35)$.

\section{Conclusion}

Based on the results of data analysis and discussion, it could be concluded that creative thinking abilities of students of SD Negeri 2 Pemaron in overall still needs to be improved because it was classified as a medium or normal category. The test results obtained by the fourth grade students of SD Negeri 2 Pemaron were quite satisfactory; it could be seen from the 
score obtained by the learners. The highest score obtained was 100 and the lowest score obtained was 60 . Based on these results, the test average was 79.78 with a high category. From the 30 students, 3 students or $10.71 \%$ gain score which was equal to the average, 14 students or $46.45 \%$ scored below average, and 13 students or $42.84 \%$ gain score above average. Creative thinking abilities of learners based on indicators (smooth thinking, flexible thinking, original thinking, and elaborative thinking) were good because not all learners had the same ability to think creatively. Thus requiring teachers to use the current method of science learning process and ensure that learners really understand the material that was being taught. Indicators of students' ability to think creatively which were the highest were the indicator of original thinking with a percentage of $84.17 \%$ and the lowest was flexible thinking with a percentage of indicator was $77.08 \%$.

Problems faced by teachers in SD 2 Pemaron to improve creative thinking ability of students was learning motivaton of students was lacking, learning facilities were inadequate, the lack of utilization of the environment as a learning resource, learning time which was quite short at the school, not getting close attention of learners, learning method was monotonous like a lecture and students often only memorize the material. The difficulties experienced by students in improving their creative thinking skills were in observing a particular object, discussion with friends, reading books from other sources in the library, and performing simple experiment. $\mathrm{T}$ The things teacher at SD Negeri 2 Pemaron did in improving the ability of creative thinking of the learners were by teaching using several methods, providing contrasting opinion so that learners actively ask, providing challenging questions and invitation to make observations or observation and experimentation around the school environment, set appropriate learning time and often call the parents of learners for sharing the problems of the children and equally provide guidance.

Based on the research results several things were suggested some of the following (a) Teachers should pay more attention to and enhance the capabilities in the indicator of flexible thinking and elaborative thinking by creating an atmosphere of learning which is more interesting and often hold discussions with questions that challenge students to create new ideas and add explanation or describe something interesting on an existing idea. (b) In the process of teaching and learning teacher should refresh the students memories about the previous lesson and informing students about the previous topic so that students could learn and be able to collect their personal experiences and prepare questions that will be presented in the classroom. The goal is to minimize the time for teachers facilitate and mediate learners and the remaining time can be used to perform experiments around the school environment. (c) Teachers need to reflect on how they teach in preparing the learners to be able to maintain their existence. They must not remain silent. Because the children will become adults, they will face a world full of opposition and problems. (d) Teacher should be able to balance between the material of the curriculum that is being applied and emerging technologies as well as the adjustments to the rules and norms of the class by giving freedom to the students, between traditional freedomm aimed at improving the ability to think creatively learners will be free of problems.

\section{References}

Bungin, Burhan. (2012). Analisis Data Penelitian Kualitatif. (The Analysis of Qualitative Data). Jakarta: Rajawali Pres

Munandar, Utami. (1999). Kreativitas \& Keterbakatan. (Creativty and Skills). Jakarta: Gramedia Pustaka Utama

Munandar, Utami. (1997). Creativity and Education: A Study of the Relationship Between 
Measurez of Creativity Thingking and a Number of Educational Variables in Indonesian Primary and Junior Secondary Schools. Jakarta: Depatermen Pendidikan dan Kebudayaan.

Susanto, Ahmad. (2013). Teori Belajar \& Pembelajaran. (Learning and Instruction Theories). Jakarta: Kencana Prenada Media Group.

Sukardi. (2011). Metodologi Penelitian Pendidikan. (Methodology of Educational Research). Jakarta: Bumi Aksara. 